\title{
Standardization of a method to study angiogenesis in a mouse model
}

\author{
DAVID FEDER ${ }^{1}$, FABIO F. PERRAZO ${ }^{2}$, EDIMAR C. PEREIRA ${ }^{3}$, SILVANA FORSAIT ${ }^{1}$, \\ CECÍLIA K.R. FEDER ${ }^{1}$, PAULO E.B. JUNQUEIRA ${ }^{1}$, VIRGINIA B.C. JUNQUEIRA ${ }^{3}$, \\ LIGIA A. AZZALIS ${ }^{2}$ and FERNANDO L.A. FONSECA ${ }^{1,3}$ \\ ${ }^{1}$ Disciplina de Farmacologia, Departamento de Morfologia e Fisiologia, Faculdade de Medicina do ABC, \\ Av. Principe de Gales, 821, Principe de Gales, 09060-650 Santo André, SP, Brasil \\ ${ }^{2}$ Departamento de Ciências Exatas e da Terra, Instituto de Ciências Ambientais, Químicas e Farmacêuticas, \\ Universidade Federal de São Paulo, Diadema, Rua Prof. Artur Riedel, 275, Pq. Eldorado, 09972-270 Diadema, SP, Brasil \\ ${ }^{3}$ Departamento de Ciências Biológicas, Instituto de Ciências Ambientais, Químicas e Farmacêuticas, \\ Universidade Federal de São Paulo, Rua Prof. Artur Riedel, 275, Pq. Eldorado, 09972-270 Diadema, SP, Brasil
}

Manuscript received on July 8, 2011; accepted for publication on November 23, 2012

\begin{abstract}
In the adult organism, angiogenesis is restricted to a few physiological conditions. On the other hand, uncontrolled angiogenesis have often been associated to angiogenesis-dependent pathologies. A variety of animal models have been described to provide more quantitative analysis of in vivo angiogenesis and to characterize pro- and antiangiogenic molecules. However, it is still necessary to establish a quantitative, reproducible and specific method for studies of angiogenesis factors and inhibitors. This work aimed to standardize a method for the study of angiogenesis and to investigate the effects of thalidomide on angiogenesis. Sponges of $0.5 \times 0.5 \mathrm{x}$ $0.5 \mathrm{~cm}$ were implanted in the back of mice groups, control and experimental (thalidomide $200 \mathrm{mg} / \mathrm{K} / \mathrm{day}$ by gavage). After seven days, the sponges were removed. The dosage of hemoglobin in sponge and in circulation was performed and the ratio between the values was tested using nonparametric Mann-Whitney test. Results have shown that sponge-induced angiogenesis quantitated by ratio between hemoglobin content in serum and in sponge is a helpful model for in vivo studies on angiogenesis. Moreover, it was observed that sponge-induced angiogenesis can be suppressed by thalidomide, corroborating to the validity of the standardized method.
\end{abstract}

Key words: angiogenesis model, hemoglobin measurement, sponge implant, thalidomide.

\section{INTRODUCTION}

Angiogenesis, the formation and growth of new capillary blood vessels, is normally under stringent control. Expansion of the capillary bed by angiogenesis is in the healthy adult limited to wound healing, physiological growth of tissues (e.g. fat, skeletal muscle) and cyclic variations in the endometrium and the corpus luteum (Hori et

Correspondence to: Fernando Luiz Affonso Fonseca

E-mail: profferfonseca@gmail.com al. 1996, Andrade et al. 1997, Kilarski et al. 2012). By contrast, uncontrolled angiogenesis can often been seen as a contributing factor in a number of angiogenesis-dependent pathologies, such as tumor growth, proliferative retinopathies, rheumatoid arthritis and psoriasis (Kilarski et al. 2012).

Stimuli such as carbon dioxide, nitric oxide, hypoxia or the increased metabolic demands associated with exercise work through multiple pathways regulate angiogenesis in a complex 
process mediated by a number of growth factors and cytokines, such as vascular endothelium growth factors (VEGF), fibroblast growth factors (FGF), angiopoietin, platelet-derived growth factors (PDGF), tumor necrosis factor- $\alpha$, and some interleukins. Elucidating exactly how angiogenic pathways are integrated in different pathophysiological contexts will be of great interest (Poon et al. 2001, Wang et al. 2005, Lahteenvuo and Rosenzweig 2012, Claesson-Welsh 2012).

Recent studies have shown that angiogenesis inhibitors are promising therapies for the treatment of patients with cancer. Most of antiangiogenic drugs block the formation of growth factors such as VEGF and others. Different approaches have been explored such as VEGF traps and inhibitors of VEGF kinase activity, anti-VEGF receptor antibodies and more recently drugs that target additional factors such as FGF, platelet-derived growth factors and others antiangiogenic drugs (Fokas et al. 2012). For example, Bevacizumab is a recombinant, humanized, monoclonal immunoglobulin G1 antibody targeted at VEGF-A that was approved by the United State's Food and Drug Administration (FDA) for the treatment of metastatic colorectal cancer, non-squamous nonsmall cell lung cancer, glioblastoma, and metastatic renal cell carcinoma. This antibody binds to and neutralizes all biologically active forms of VEGF-A (e.g. VEGF-A165) which suppresses growth of tumors and inhibits progression of metastatic disease (Itamochi and Kigawa 2012).

Thalidomide ( $\alpha$-N-phthalimido glutarimide) is a glutamic acid derivative that was first introduced in 1954 as a sedative drug but was withdrawn from the market due to its teratogenic effects. Thalidomide has various pharmacological properties such as immunomodulatory, antiinflammatory and antiangiogenic activity and it has been used successfully for various inflammatory and autoimmune diseases and some tumors (Amirshahrokhi and Ghazi-Khansari 2012).
A variety of animal models have been described to provide more quantitative analysis of in vivo angiogenesis and to characterize pro- and antiangiogenic molecules (Andrade et al. 1997). The assays for angiogenesis that are frequently used include the chick chorioallantoic membrane (CAM), transparent chambers, matrix or sponge implants and the cornea model. All utilize the pre-existing vasculature as a source of vessels that expand into an implanted or injury-induced matrix. However, none of these methods and their modifications are ideal as they are difficult to quantify or observe vascular growth continuously. It is necessary to establish a quantitative, reproducible and specific method for studies of angiogenesis factors and inhibitors (Andrade et al. 1987).

The present study aimed to evaluate and quantify the angiogenic potential of thalidomide, by in vivo mice sponge implantation assay. This method was chosen to be standardized as it was reproducible, not dependent on the observer's experience, and could be applied in the Faculdade de Medicina do ABC (Andrade et al. 1997, Ferreira et al. 2004, Schönherr et al. 2004).

\section{OBJECTIVES}

1) To standardize a method for the study of angiogenesis.

2) To investigate the effects of thalidomide on angiogenesis.

\section{MATERIALS AND METHODS}

Animals from the Faculdade de Medicina do ABC were used. Throughout the experiment, all animals were maintained on a 12:12-h light-dark cycle, under controlled temperature and humidity conditions and with free access to food and water. The experimental protocol was approved by the Ethical Committee for Animal Experimentation (EAEC). Efforts were made to minimize animal suffering and to reduce the number of animals used. 
SPONGE IMPLANTATION

Sponges $(0.5 \times 0.5 \times 0.5 \mathrm{~cm})$ were aseptically implanted subcutaneously on the back of Balb/c mice $(n=14)$ under general anesthesia with ketamine (100 $\mathrm{mg} / \mathrm{kg})$ and xylazine $(10 \mathrm{mg} / \mathrm{kg})$, intraperitoneally.

\section{THALIDOMIDE TREATMENT}

Animals were randomly divided into two groups:

a) Control group - 7 animals received by gavage a single daily dose of $0.2 \mathrm{~mL}$ of milk for a week.

b) Experimental group - 7 animals were treated with a single daily dose of thalidomide (200 mg/ $\mathrm{kg}$ ) diluted in milk, since the drug is not soluble in water, by gavage for a week.

Animals were monitored daily.

\section{EVALUATION OF ANGIOGENESIS}

After seven days, the mice were anesthetized as previously described. A blood sample from circulation was obtained in order to compare both hemoglobin values from serum and sponge. The sponges were carefully removed and the contents were homogenized in $2.0 \mathrm{~mL}$ of saline and centrifuged at $10,000 \mathrm{x} g$ for 15 minutes. The supernatant was filtered through a 0.22 micron filter (Millipore).

Hemoglobin concentration was determined spectrophotometrically at $540 \mathrm{~nm}$ by using the hemoglobin assay kit (Sigma Drabkin's reagent).

\section{STATISTICAL ANALYSIS}

Hemoglobin content in sponge and in serum was tested using nonparametric Mann-Whitney test. GBstat 9.0 software was used. $\mathrm{p}<0.05$ was considered statistically significant.

\section{RESULTS}

Table I shows ratio between hemoglobin values obtained in sponge and in serum. It is possible to verify that the sponge-induced angiogenesis can be suppressed by thalidomide.
TABLE I

Ratio between hemoglobin content in sponge and serum.

\begin{tabular}{ccc}
\hline Animal & Control group & $\begin{array}{c}\text { Thalidomide } \\
\text { group }\end{array}$ \\
\hline 1 & 0.921 & 1.015 \\
2 & 0.885 & 0.545 \\
3 & 0.639 & 0.585 \\
4 & 0.645 & 0.411 \\
5 & 1.062 & 0.586 \\
6 & 0.636 & 0.467 \\
7 & 0.612 & 0.348 \\
\hline Mean+/- SD & $0.77+/-0.18$ & $0.56+/-0.22 *$
\end{tabular}

$* p \leq 0.05$

\section{DISCUSSION}

A number of pro- and antiangiogenic molecules have entered clinical trials for a variety of diseases. However, in spite of promising results obtained from animal models, many therapies have failed when applied in the clinic. These discrepancies suggest that current in vivo angiogenesis assays should be improved in order to better understand mechanisms nondevelopmental angiogenesesis during tissue vascularization and repair (Kilarski et al. 2012). Moreover, one of the difficulties of current methods of measuring angiogenesis is the assessment of vascularization which is usually to subjective to be reproducible between laboratories and even between individuals (Andrade et al. 1987).

This paper describes a quantitative method for the study of angiogenesis in mice. It was adapted from Andrade et al. (1987, 1997) and it offers several advantages: (i) an objective assessment of angiogenesis; (ii) reproducibility and (iii) evaluation of angiogenesis by comparison between hemoglobin content in serum and in sponge.

We have shown that the sponge-induced angiogenesis can be suppressed by thalidomide. Thalidomide is listed as a drug that potentially would target multiple components of tumor microenvironment (angiogenesis, inflammation, 
proliferative activity). Despite these wellcharacterized effects and a large number of publications, the results of the effects of thalidomide on a number of clinical and experimental protocols are rather contradictory and/or inconsistent (Souza et al. 2012).

Thalidomide was approved by the FDA for the treatment of erythema nodosum leprosum (ENL) and multiple myeloma. It has also been demonstrated that thalidomide or its analogs are effective in the treatment of rheumatoid arthritis, Crohn's disease, prostate cancer, Behcet's disease, chronic host-versus-graft disease, lupus erythematosis and HIV-associated oral ulcers. However, teratogenicity, peripheral neuropathy and other adverse effects of thalidomide have led to the design of its new analogs with low toxicity (Amirshahrokhi and Ghazi-Khansari 2012).

The mechanism of thalidomide action is not yet known, but hypotheses include decreased levels of tumor necrosis factor (TNF), interleukin and inhibition of production and co-stimulation of CD8. Reports also suggest that thalidomide has a role in regulating helper cells (Th2). This would increase the production of Th2 cytokines IL4 and IL5 and inhibit the production of inflammatory lymphocytes (Th1) cytokine IFN and range in peripheral blood cells stimulated by antigens and mitogens (Pridgeon and Drake 2005). Laboratory studies performed with rabbit cornea show that thalidomide has antiangiogenic properties, possibly by blocking the action of potent angiogenic factors such as fibroblast growth factor (bFGF) and vascular endothelial growth factor (VEGF). In vitro studies have suggested that the inhibitory effect of angiogenesis is caused by certain metabolites formed in vivo rather than the parent compound. Another possibility suggests that inhibition of TNF- $\alpha$ may also be responsible for inhibiting angiogenesis, since TNF- $\alpha$ has a positive effect on angiogenesis (Kumar and Chhibber 2011).

\section{CONCLUSIONS}

1) Standardization of a sponge-induced angiogenesis in mice quantitated by comparison between hemoglobin content in serum and in sponge.

2) Sponge-induced angiogenesis can be suppressed by thalidomide.

\section{RESUMO}

No adulto, a angiogênese é restrita a poucas condições fisiológicas. Ao contrário, a angiogênese descontrolada frequentemente está associada a patologias dependentes de angiogênese. Vários modelos animais foram descritos para ajudar na análise quantitativa da angiogênese in vivo e caracterizar moléculas pró e antiangiogênicas. Porém, ainda é necessário estabelecer um método quantitativo, reproduzível e específico para estudar os fatores pró e antiangiogênicos. Os objetivos deste trabalho foram padronizar um método para estudar angiogênese e investigar os efeitos da talidomida na angiogênese. Esponjas de $0,5 \mathrm{x}$ $0,5 \times 0,5 \mathrm{~cm}$ foram implantadas no dorso de camundongos controles e tratados (talidomida $200 \mathrm{mg} / \mathrm{K} / \mathrm{dia}$, por gavagem). Após sete dias, as esponjas foram retiradas. Avaliou-se a quantidade de hemoglobina na esponja e na circulação. A razão obtida entre esses valores foi testada por meio do teste não paramétrico Mann-Whitney. Os resultados mostraram que a angiogênese induzida pela esponja e quantificada por meio da razão hemoglobina esponja/circulação é um modelo útil para estudos in vivo de angiogênese. Além disso, observou-se que a angiogênese induzida pela esponja diminui na presença de talidomida, corroborando para a validação do método padronizado.

Palavras-chaves: modelo de angiogênese, avaliação de hemoglobina, implante de esponja, talidomida.

\section{REFERENCES}

AMIRSHAHROKHI K AND GHAZI-KHANSARI M. 2012. Thalidomide attenuates multiple low-dose streptozotocininduced diabetes in mice by inhibition of proinflammatory cytokines. Cytokine: 60: 522-527. http://dx.doi.org/10.1016/ j.cyto.2012.07.029.

ANDRADE SP, FAN T-PD AND LEWIS GP. 1987. Quantitative invivo studies on angiogenesis in a rat sponge model. Br J Exp Path 68: 755-766. 
ANDRADE SP, MACHADO RDP, TEIXEIRA AS, BELO AV, TARSO AM AND BERALDO WT. 1997. Sponge-induced angiogenesis in mice and the pharmacological reactivity of the neovasculature quantitated by a fluorimetric method. Microvasc Res 54: 253-261.

Claesson-Welsh L. 2012. Blood vessels as targets in tumor therapy. Upsala J Med Sci 117: 178-186.

FERREIRA MAND, BARCELOS LS, CAMPOS PP, VASCONCELOS AC, TeIXeIra MM And Andrade SP. 2004. Spongeinduced angiogenesis and inflammation in PAF receptor-deficient mice (PAFR-KO). Brit J Pharmacol 141: 1185-1192.

FoKas E, McKenNa WG AND Muschel RJ. 2012. The impact of tumor microenvironment on cancer treatment and its modulation by direct and indirect antivascular strategies. Cancer \& Metastasis Rev 31: 823-842. http://www. springerlink.com/content $/ 2782 \times 737 \mathrm{~m} 8315 \mathrm{wgl} /$ fulltext.pdf

Hori Y, Hu D-E, YASUI K, SMITHER RL, GRESHAM GA AND FAN T-PD. 1996. Differential effects of angiostatic steroids and dexamethasone on angiogenesis and cytokine levels in rat sponge implants. Br J Pharmacol 118: 1584-1591.

ITAMOCHI H AND KigawA J. 2012. Clinical trials and future potential of target therapy for ovarian cancer. 2012. Int J Clin Oncol 17: 430-440. http://www.springerlink.com/ content/h62r04t134g361h0/fulltext.pdf

Kilarski WW, PETERSSON L, Fuchs PF, ZiELINSKI MS AND GERWINS P. 2012. An in vivo neovascularization assay for screening regulators of angiogenesis and assessing their effects on pre-existing vessels. Angiogenesis 15: 643-655. http://www.springerlink.com/content/132pu18520049645/ fulltext.pdf
KuMAR V AND CHHIBBER S. 2011. Thalidomide: an old drug with new action. Chemother 23(6): 326-334.

LAHTEENVUO J AND ROSENZWEIG A. 2012. Effects of aging on angiogenesis. Cir Res 110: 1252-1264.

Poon RT, NG IO, LaU C, Yu WC, FAn ST and Wong J. 2001. Correlation of serum basic fibroblast growth factor levels with clinicopathologic features and postoperative recurrence in hepatocellular carcinoma. Am J Surg 182: 298-304.

PridgeOn S AND DRAKE M. 2005. Thalidomide and its use in renal and prostate cancer. Cancer Ther 3: 65-76.

SCHÖNHERR E, SUNDERKÖTTER C, SCHAEFER L, THANOS S, GrÄSSEl S, OldBerg A, IOZZO RV, Young MF AND KRESSE H. 2004. Decorin deficiency leads to impaired angiogenesis in injured mouse cornea. J Vasc Res 41(6): 499-508.

Souza CM, CARVALHo LF, VieIRA TD, SiLVA AC, Lopes MT, FERREIRA MA, ANDRADE SP AND CASSALI GD. 2012. Thalidomide attenuates mammary cancer associatedinflammation, angiogenesis and tumor growth in mice. Biomed Pharmacother 66: 491-498. http://www. sciencedirect.com/science/article/pii/S0753332212000546

WANG L, Shi GG, YaO JC, Gong W, Wei D, Wu TT, AJANi JA, HUANG S AND XIE K. 2005. Expression of endothelial nitric oxide synthase correlates with the angiogenic phenotype of and predicts poor prognosis in human gastric cancer. Gastric Cancer 8(1): 18-28. 